\title{
Pursuing Digital Transformations through Fluorescent Green Bunnies: \\ The Poetics of Technology
}

\section{Andrew Prescott}

* AL 5954, London, UK | Llan-non

Andrew Prescott is Professor of Digital Humanities at the University of Glasgow. He trained as a medieval historian and his PhD thesis focussed on the Peasants' Revolt of 1381. He was from 1979 to 2000 a Curator of Manuscripts in the British Library, where he was involved in some of the Library's first digitisation projects, including Electronic Beowulf. He has also worked in digital humanities units and libraries at the University of Sheffield, University of Wales Lampeter and King's College London. From 2012-2018, Andrew was Theme Leader Fellow for the Arts and Humanities Research Council strategic theme of Digital Transformations. Publications include English Historical Documents (1988), Towards the Digital Library (1998), The British Inheritance (2000), The Benedictional of St Æthelwold: A Masterpiece of Anglo-Saxon Art (2002) and London and the Kingdom (2008), as well as articles archives, and the history of on the 1381 revolt, the history of Freemasonry.

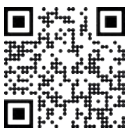
2000. Courtesy of the artist. 
I am a historian who is beguiled by the remnants of the past we encounter in libraries, archives and museums. As a postgraduate student, I immersed myself in the archives of the late fourteenthcentury English state. I found and find these records compelling because of the way we encounter in them so many humble forgotten ordinary lives conveying extraordinary stories. Because of my fascination with these archives, I got a job as a manuscript curator at the British Library where I explored manuscripts and books from many different cultures and periods and investigated the way the institutional history of libraries and archives shapes and mediates our engagement with the past.

I was very fortunate to participate in some of the British Library's early experiments in digitisation and the use of the web in the early 1990s. In particular, I was the curatorial contact for the major Electronic Beowulf project, edited by my friend and leading Beowulf scholar Professor Kevin Kiernan of the University of Kentucky. ${ }^{1}$ Electronic Beowulf was not only a digital colour facsimile of the unique manuscript of this celebrated Old English poem but also used special lighting techniques to record details of the manuscript not visible with the naked eye and gave access to digital images of other early records of the Beowulf text. Fired by the excitement of transmitting for the first time images of medieval manuscripts across the Atlantic and experimenting with ways in which the first web browsers could make images of manuscripts readily accessible, I became addicted to exploring the ways in which digital technologies can bring us closer to the manuscript and archives which have entranced me since I was a student.

I left the British Library in 2000 to work in the Humanities Research Institute at the University of Sheffield. The Humanities Research Institute, now the Digital Humanities Institute, has for thirty years been one of the pioneers in the intersection between cultural heritage and digital technologies. ${ }^{2}$ Broadly my interests since 1990 have remained the same: how are digital imaging, network access and other technologies transforming libraries and archives? Although my interests have remained constant, the way in which the subject area is described has shifted. Initially, there were a series of groups which worked on the relevance of computing to particular subject areas: history and computing, literary and linguistic
1 Kevin Kiernan (2015),

Electronic Beowulf 4.0, programmed by lonut Emil lacob, ebeowulf. uky.edu
2 Digital Humanities Institute at dhi. ac.uk 
3 Willard McCarty (2005), Humanities Computing, (Basingstoke: Palgrave Macmillan).

4 John Unworth, Ray Siemens and Susan Schreibman (2007), $A$ Companion to Digital Humanities, (Chichester: John Wiley).

See also: Melissa Terras, Julianne Nyhan and Edward Vanhoutte,(2013), Defining Digital Humanities: a Reader, (Farnham: Ashgate). See also Dorothy Kim and Jesse Stommel, (2018), Disrupting the Digital Humanities, (Santa Barbara: Punctum Books).

\section{Cf Digital} Scholarship in the Humanities at academic.oup.com/ dsh, and for the Alliance of Digital Humanities, see adho.org

6 Charles Forsdick, Henry French, Andrew Prescott and Barry Smith (2019), Working at the Intersections: Arts and Humanities Research Council Strategic Themes 2010-2019, (Liverpool: University of Liverpool).

7 Keri Facer and Bryony Enright (2016), Creating Living knowledge: the Connected Communities Programme, Com- computing, and so on. By the 1990s, 'humanities computing' was a useful catch-all title for these activities. ${ }^{3}$ However, as the range of digital activity increased and network collaboration became more prominent, the term 'digital humanities,' introduced in 2004 by the Blackwell Companion edited by John Unsworth, Ray Siemens and Susan Schriebman, was adopted, prompting a debate which still rumbles on about what exactly are the digital humanities. ${ }^{4}$ I have enjoyed the title of Professor of Digital Humanities since 2010 and I regard the term as simply a convenient way of designating those interests and enthusiasms I have held since my days in the British Library. There is no other convenient expression for them. I am an extremely well-informed observer and commentator on the way in which digital methods and affordances have transformed the study of the arts and humanities but by no stretch of the imagination can I be regarded as a technical expert or computer whizz. My digital understanding remains grounded in and shaped by my experience as a librarian. I do not propose here to enter further into the discussions about what the digital humanities are and their relationship to the disciplines which historically make up the humanities. I want simply to note that much of digital humanities work is concerned with modelling humanities methods and source materials for computational analysis. A glance at the major digital humanities journals such as Digital Scholarship in the Humanities published by Oxford University Press or the abstracts for the major Digital Humanities Conferences organised by the Alliance of Digital Humanities Organisations shows the prominence of quantitative methods and of formal modelling. ${ }^{5}$ Digital humanities can often have an abstract and formal character, and many digital humanities practitioners look instinctively to scientific methods in developing their discipline.

In 2012, I was honoured to be appointed theme leader fellow for the Arts and Humanities Research Council (AHRC) strategic theme of Digital Transformations. This was one of four strategic themes established by the AHRC, the others being Translating Cultures, Care for the Future and Science in Culture. ${ }^{6}$ The strategic themes also worked closely with the major Research Councils UK Connected Communities programme.7 I was Theme Leader Fellow for

Digital Transformations until 2019, and it proved to be an

$$
\begin{aligned}
& \text { munity-University } \\
& \text { Relationships and } \\
& \text { the Participatory } \\
& \text { Turn in the Produc- } \\
& \text { tion of Knowledge, } \\
& \text { (Bristol: University } \\
& \text { of Bristol Press). }
\end{aligned}
$$


engrossing, mind-bending and intellectually stretching time. If my work at the British Library in the early days of the web at the beginning of the 1990s was exhilarating, it was nevertheless often in my comfort zone. Making images of manuscripts available via the internet was a natural extension of my previous work as a librarian. My work in the Digital Transformations theme challenged more strongly many of my preconceptions and led me into new areas. I am still trying to absorb and process the research journey of those intense Digital Transformations years. This chapter draws on some of the material I wrote in the course of the fellowship, but is also part of my continuing attempt to digest what I learnt during that heady period.

The AHRC Digital Transformations theme funded over 100 projects between 2010 and 2018. These included some of the largest digital projects which the AHRC had ever funded at that time. These beacon projects comprised Digital Panopticon which used large-scale data linking methods to reconstruct the lives of people convicted as criminals between 1780 and 1925; Transforming Musicology which explored a range of advanced methods for automated reading and analysis of music; and Fragmented Heritage which developed citizen science tools for location of archaeological remains and reconstruction of fragile heritage. ${ }^{8}$ The theme also included a project with the British Library which produced a report on The Academic Book of the Future. ${ }^{9}$ There were also a wide range of smaller projects which included pioneering work on Big Data in the arts and humanities. The range of subjects and methods of the projects in the Digital Transformations portfolio was striking, encompassing the linking of data sets from the classical world, the study of reading networks and music apps facilitating remixing by listeners through to 3D printing of data, the value of 'the internet of things' in care homes, and distributed musical performances.10 My initial outlook when I started my Digital Transformations fellowship reflected my library background.

I imagined that digital transformations might be driven by doing bigger and more exciting things with data-by linking large data sets in different ways, by developing new forms of visualisation, by modelling subject information in innovative ways. It meant I used words
8 Digital Panopticon at digitalpanopticon.org; Transforming Musicology at tm.web.ox.ac.uk; and Fragmented Heritage at fragmented.heritage. com

9 The Academic Book of the Future at academicbookfuture.org

10 For project descriptions, see Diane Scott, (2019), Performing, Remixing and Reimagining Data, (Glasgow: University of Glasgow), and also Andrew Prescott (Ed.) (2015), Big Data in the Arts and Humanities: Some Arts and Humanities Research Council Projects, (Glasgow: University of Glasgow). 
like 'new' and 'change' and 'innovation' a lot. This was probably the assumption of AHRC when it set up the theme-it is telling that during the period of the theme, the term 'digital transformation' became a common business euphemism for cost-cutting, redundancies and restructuring. The sort of issues I assumed were pressing in 2010, like sustainability, sharing and reuse of data, reflected this outlook. The advent of social media and the rise of smartphones at about that time seemed initially to reinforce these assumptions.

My preconceptions were almost immediately challenged and the story of my fellowship became one of developing and embracing alternative perspectives on technology. The challenge came from talking to artists, curators and others who were engaged in practice-based research. They questioned the emphasis on innovation and project management I brought from libraries and digital humanities. They argued for a more multi-faceted view of digital cultures with stronger critical frameworks. This chimed with an increasing awareness among humanities scholars of the biases and social and cultural assumptions embedded in emerging digital resources. Practice-based researchers also brought a strong awareness that the digital world was more than just data. With the growth of the internet of things, there was an increasing awareness of the materiality of the digital world. That materiality suggested many different perspectives that I found aligned with my experience of manuscripts and rare books. I became aware of the ways in which digital creativity intersects with craft and learned how craft practice can inform our digital engagement as strongly as data science.

As my fellowship developed, it became clear that there was an urgent need for humanities scholars from disciplines like history and literature to engage more strongly with artists, curators and other practice-based researchers in developing their digital methods. While such data science approaches as linking, quantification and visualisation remain valuable, a dialogue with practice-led research can generate radically different insights and articulate fresh visions of what digital technology might achieve. This does not mean spurning links with science, far from it. Indeed, it became increasingly evident that artists and designers were often engaging more deeply and critically with scientific developments than many humanities scholars. They were making use in their work of latest developments in areas like bioscience and blockchain. As my work proceeded, I became

corporeal trace [ko:'po:rial tress]

initial incarnation developed by benedict de spinoza in his 1665 classic, ethics, demonstrated in geometrical order. here spinoza sets out a wildly different way to 'see', 'look', 're-remember'-one that no longer requires a 1:1 correlation of an eye to the 'out there' of life and limb. we find the ghost(ing) of image/imagination imprinted on the flesh body in a way that cannot separate out 'mind' from the body-soul of which it is a part. first sign of consciousness as a living being, bringing to presence 'intelligence' without the need for internalised 'perception', 'intuition' and other metaphysic irritants. go figure. 
convinced that the key to truly radical digital transformations in the humanities is a closer dialogue and integration of artistic practice. We can place this in a wider cultural and historical context. The advent of the computer in the humanities in the 1960s caused concerns that an invasion of technology posed an existential threat to humanities scholarship. In 1965, the historian Franklin Pegues was cautiously optimistic about the assistance computers could provide but insisted that machines must be kept in their place:

"The machine must serve to free the humanist from time-consuming labor and enlarge his horizons for greater and more important accomplishments. In short, the machine can help the scholar be a better humanist. It will be a sad day for the humanities if scholars seek to undertake only that work which can be computer-oriented."11

This assumption that the machine must only ever be a tool and subservient to the higher aims of humanities scholarship remains common. The debate about the exact nature and scope of the digital humanities may partly be linked to this nervousness about the role of quantification and more scientific methods in the humanities.

Although things have moved on a great deal since Pegues wrote in 1965 and the use of computers by humanities scholars for a variety of purposes is widespread, digital methods are still only patchily embedded in the scholarly mindset of the humanities.

The roots of this uncertainty about the digital lie in the way much of our cultural history of the past two hundred years has been defined by anxieties about the growth of a technological and commercial society. In the nineteenth century, in face of the first great waves of industrialisation, Samuel Taylor Coleridge bewailed "the philosophy of mechanism which, in everything that is most worthy of the human intellect, strikes Death."12 Matthew Arnold declared that "Faith in machinery is our besetting danger."13 Such advocates of what Raymond Williams identified as the great tradition dominating British society in the nineteenth and early twentieth centuries saw high culture as a means of staving off the threat of an industrial society ruled by money and commercialism. The ubiquity of the computer challenges the cultural defences erected by commentators such as Coleridge and Arnold. Using computers in literary criticism starts to look very much like an industrial enterprise, which is one reason why
11 Franklin J. Pegues (1965), “Computer Research in the Humanities," in Journal of Higher Education, (London: Taylor and Francis), vol 36 , no 2 , 105-8.

12 Samuel Taylor Coleridge (2014 [1895 ]),

"Letter to William Wordsworth, 30 May 1815," in Ernest Hartley Coleridge (Ed.), Letters of Samuel Taylor Coleridge, Vol II, eBook \#44554, The Project Gutenberg at gutenberg.org, 649.

13 Stefan Collini (1993), Arnold, Culture and Anarchy and other writings, (Cambridge: Cambridge University Press), 63. 
14 Andrew Prescott (2012), “An Electric Current of the Imagination: What the Digital Humanities Are and What They Might Become," in Journal of Digital Humanities, (New York: Springer), Vol 1, no 2, at journalofdigitalhumanities.org/1-2/ an-electric-current-of-the-imagination-by-andrew-prescott/

15 Prescott, An Electric Current of the Imagination, Ibid.

16 Cf digitaltransformations.ac.uk

17 Cf Bronan Ferran and Andrew Prescott at mixcloud.com/Resonance/playlists/ making-conversations/ digital humanities has frequently provoked such suspicion.

In 2012, I gave a lecture at King's College London entitled An Electric Current of the Imagination: What the Digital Humanities Are and What They Might Become. ${ }^{14}$ I pointed out how in many ways artistic practice integrated digital technologies into a wider cultural and creative vision in a more exciting fashion than had so far been achieved in the humanities. I argued that artistic practice offers a powerful means of fostering new creative and critical alignments between art and technology. A digital humanities suffused by the visions generated by a close engagement with artistic practice could potentially be the means of breaking down the old binaries between art and technology that have grown up since the Industrial Revolution. As I stated at the conclusion of my lecture, "Such a new conjunction of scientist, curator, humanist and artist is what the digital humanities must strive to achieve. It is the only way of ensuring that we do not lose our souls in a world of data."15

My Digital Transformations fellowship comprised a series of conversations and collaborations which explored the potential and possibilities of these approaches. Together with Jon Rogers of the University of Dundee, the curator Irini Papadimitriou at the Victoria and Albert Museum, and Michelle Thorne and others from the Mozilla Foundation, we introduced a digital humanities strand into the annual Digital Design Weekend at the Victoria and Albert Museum, and produced a series of booklets documenting the cross-currents of the many different projects included in these lively public events. ${ }^{16}$ The annual Digital Design Weekend and Mozilla Festivals were wonderful venues for building conversations which crossed many different boundaries and headed off in many directions. They demonstrated how the study of ancient manuscripts might cross connect with the 'internet of things', and how linguists could help us think about the dangers and limitations of a voice-controlled internet. A key figure in guiding and developing my exploration of cross-sectoral dialogue and collaboration was the writer and curator Bronac Ferran. Bronac and I curated a series of programmes on Resonance FM called Making Conversations, a series of chats with a wide range of guests exploring in a free-wheeling fashion how making, craft and practice in a variety of fields are both being transformed by and have the potential to transform digital culture. ${ }^{77}$ The archives of the Resonance 
FM programmes Bronac and I produced are a vast and fascinating toolkit showing how craft and artistic practice can promote digital transformation. We spoke with the artists Paul and Daniel Brown about their creation of art work using algorithms and other methods of automatic generation and explored how that can be seen as a new form of craft practice. ${ }^{18}$ We debated the nature of craft and making with theorists and practitioners such as Tim Ingold, Justin Marshall and Jon Rogers. We looked back to such formative events as the Cybernetic Serendipity exhibition at the ICA in 1968 and the Destruction in Art symposium in 1966. We remembered how the Scratch Orchestra reimagined the hierarchies of artistic creation. For me, the Resonance FM broadcasts were a fascinating experiment in qualitative research which probed how artistic practice enables us to reimagine the digital.

18 On the work of
Paul and Daniel
Brown, see Paul
Brown and Bronac
Ferran (2017), "Art
That Makes Itself
and other gener-
ative beginnings,"
in Interdisciplinary
Science Reviews,
(London: Taylor

and Francis), no 42, 158-68. See also: Bronac Ferran (2015), Art That Makes Itself: Brown \& Son Purveyors of Digital Images since 1968, (London: Brown \& Son).

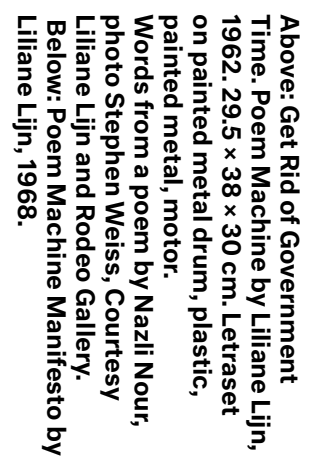




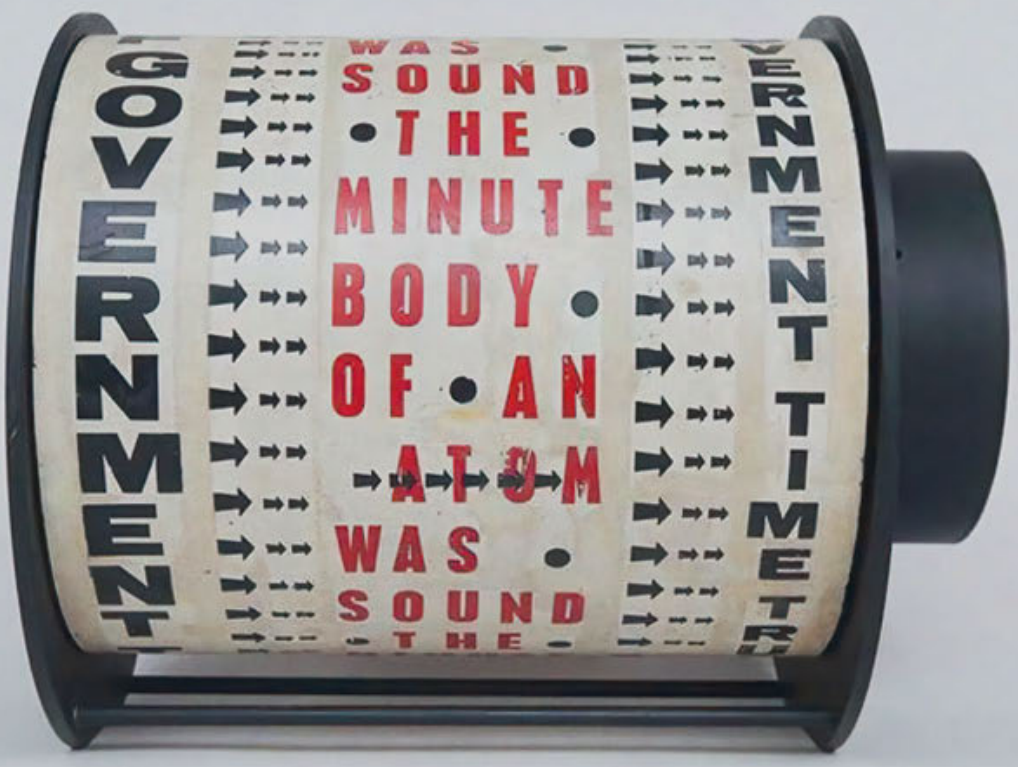

POEM MACHINE $=$ VISION OF SOUND

\section{SEE SOUND AS MOVING LINES OF LIGHT}

The words we utter travel in sound waves vibrating through the air into our inner ear. When we see the written word we forget these letters are symbols of vibrations.

WORDS $=$ VIBRATIONS $=$ BNBRGY

When I put words on cylinders and cones and make Poem Machines, I want the word to be seen in movement splitting itself into a pure vibration until it becomes the energy of sound.

Pirst Poem Machines - 1962-3

Action - Words - Power - Words

The Word Becomes Bnergy

1964-5 Poem-Machine takes on shape, becomes Poemkon. Conic shape bends itself to the dematerialisation of the word. At the narrowest point of the cone the words may still be readable wheras at the base they become a vibration pattern. The word accelerated loses its identity and becomes a pattern pregnant with energy. It is pregnant with the energy of its potential meaning should it once again become a word.

DISSOLVE THE IMAGES CREATED BY WORDS AND SEE SOUND

L. Iijn 1968 

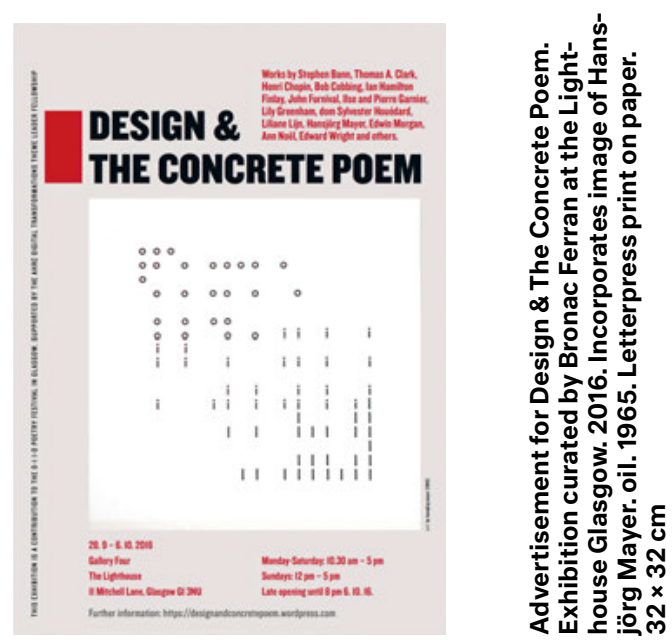

Another key event held under the auspices of my AHRC fellowship was an exhibition, Design and the Concrete Poem curated by Bronac Ferran at the Lighthouse Gallery in Glasgow from 28 September-6 October 2016. This exhibition introduced me to the work of many artists whose exploration of the materiality of text and poetry I found compelling. Design and the Concrete Poem illustrated how the roots of a poetic interrogation of technology reached back beyond the digital age, as could be seen in the early to mid-20th century experimentation by artists Dom Sylvester Houédard with typewriters in the 1960s or the creative use by Bob Cobbing of stencil duplicating machines and photocopiers in the 1970s and 1980s. ${ }^{19}$ These works showed how textual technology could be stretched and manipulated to enable us to reimagine both the text and the technology.

Design and the Concrete Poem also featured the work of Liliane Ljin, such as her Poem Machines series (1962-5) created with Letraset on metal drums. For me, the way in which the history of industrialisation informs our understanding of digital changes and the complex interaction between craft, small workshops and factories are fundamental themes, and Liline Ljin's fascination with industrial processes and images speaks powerfully to this. Her exploration of Dickensian engineering workshops in London in the late 1960s inspired her Material Alphabet (1970) which is an eloquent testimony to the creative possibilities of an artistic response to technology. 
Likewise, a poem by Pierre and Ilse Garnier cut on a Gestetner duplicating stencil, shown for the first time in the Glasgow exhibition, offered both a novel view of textual materiality and an elegy for an obsolete technology. Throughout the period of my AHRC Fellowship, one artist whose work I found consistently helpful in thinking about the interaction between technology, communication and our human condition is the Chicago-based Eduardo Kac.

Thanks to Bronac Ferran, a dialogue with Eduardo became a central feature of the work in my fellowship. Eduardo made a number of presentations designed to build up dialogue between artistic practice and new disciplinary audiences, such as for example a presentation at the International Congress on Medieval Studies at Western Michigan University in 2016. He appeared in our Resonance FM radio series and took part in sessions at the Victoria and Albert Museum and elsewhere. Above all, we organised two exhibitions of Eduardo's work in London in 2018. Poetry for Animals, Machines and Aliens: the Art of Eduardo Kac was held at the Furtherfield Gallery from 7 April-28 May. This was followed by ...and the Bunny Goes POP! tales of a rabbit gone viral at the Horse Hospital from 2-21 June 2018.

Both exhibitions in different ways were reflections on the poetics of technology, a theme that has preoccupied Kac throughout his career. Poetry is challenging. A poem questions our certainties, makes us see the world from different angles and, by encouraging us to pause and reflect, subverts that mechanistic goal-oriented outlook which so horrified Coleridge and Arnold but nevertheless dominates the modern world. Technology can give words and letters new shapes and resonances and, in so doing, subvert a consumer-oriented view of technology. The presentations of Kac's work at Furtherfield and the Horse Hospital provided striking illustrations of these themes.

There can be no more imposing expression of technological achievement than the International Space Station.

One of the most fascinating aspects of the video of Eduardo Kac's space poem Inner Telescope, performed in 2016 by the French astronaut Thomas Pesquet, shown in the Furtherfield exhibition, are the interior shots of the cramped space station, jam-packed with wires, containers and panels from innumerable scientific experiments. The confined space station contrasts with the expansive views of the earth, visible through the space station windows. 


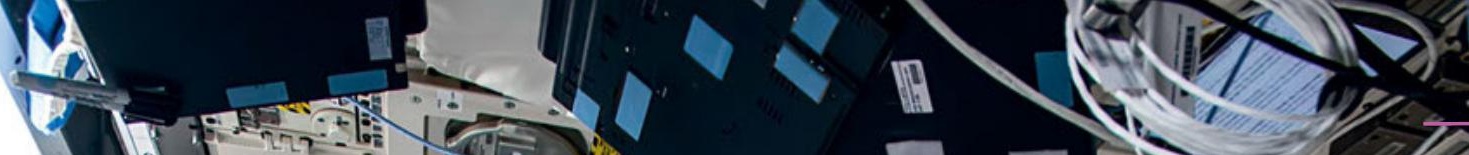

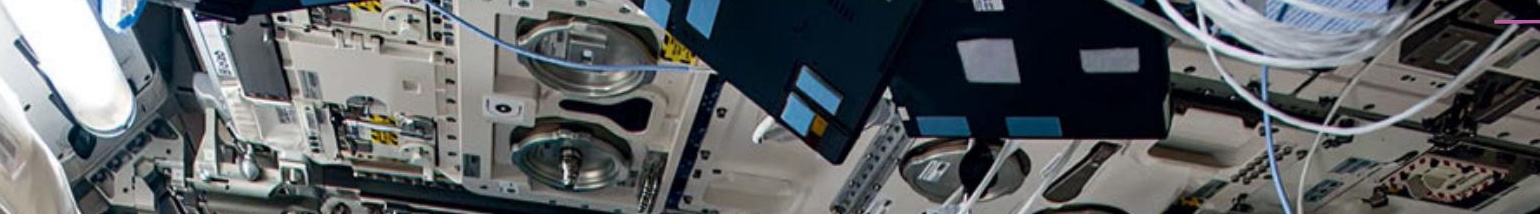
4 iा

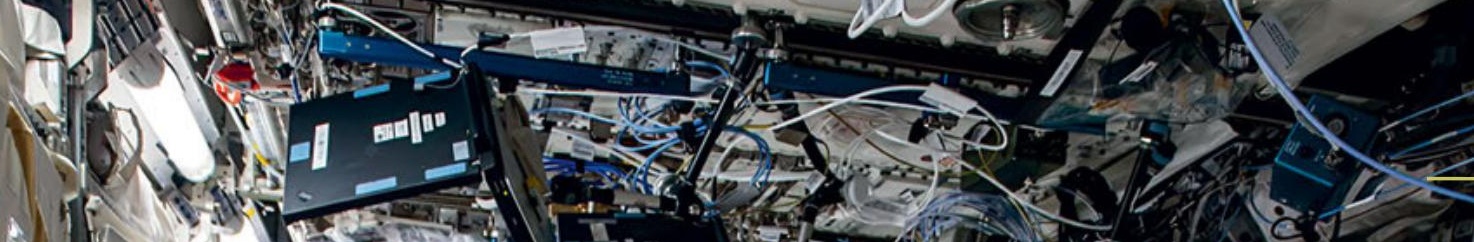

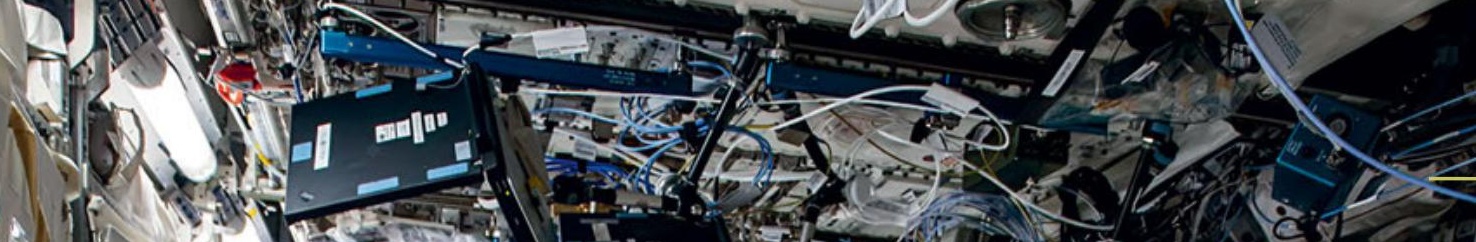
1) ITE

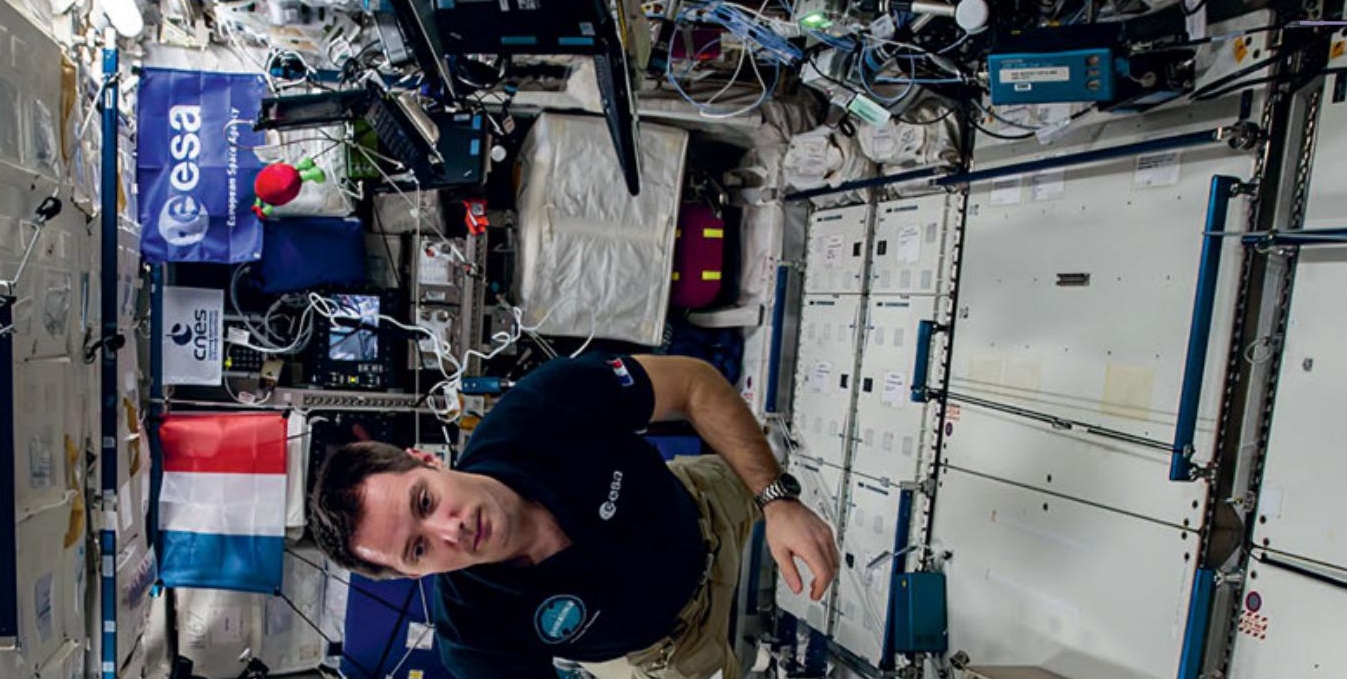

1,10 (1)

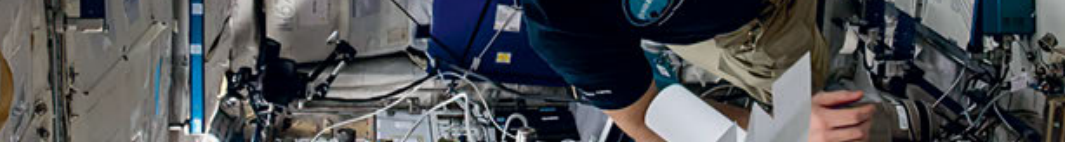

(.) 1 (1)

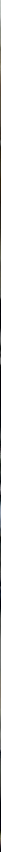


20 Eduardo Kac, Ed., (2007), Media Poetry: an International Anthology, 2nd edition (Chicago: Intellect).
This contrast itself seems like a commentary on the puny character of human technological ambitions. Kac proposed the idea of space poetry in 2007. He pointed out that weightlessness would affect the temporal and physical logic of a poem, while the readers' sensory engagement with the act of reading would also be different under zero gravity. Inner Telescope memorably shows how a simple performance such as cutting paper may be different in zero gravity, while the movement of the paper (cut into a form representing the word 'Moi') seems to epitomise the fragility of textual communication. In the rigidly scheduled life of the space station, Inner Telescope uses poetry to pause and reflect on the complex interrelationship of humanity, technology and the wider universe.

One major thread of Kac's art has been the relentless interrogation of technology to create radical and original poetic visions. ${ }^{20} \mathrm{Kac}$ experimented with the potential of the typewriter to allow different juxtapositions and textual shapes in his Typewritings of 1981-2 and from these experiments sprang his first digital poem, Não! (No!), in 1982-4. Não! was presented on an electronic signboard with an LED display with fragmentary text blocks, encouraging the reader to guess at the links between them. The digital poems shown in the Furtherfield exhibition illustrated how Kac makes use of digital technologies to redefine the relationship between the reader and text and to reveal new poetic elements in short words and phrases. In Accident (1994), a digital loop introduces shifts and uncertainties into a text, recalling the nervous hesitation when two lovers meet, but also causing the reader's perception of the text to change as the piece progresses. Another remarkable pioneering digital poem which was shown at Further-field, Letter (1996), uses virtual reality markup language to create a three-dimensional spiral of text which the reader can spin, invert, twist and explore from every conceivable angle. The text appears to be a single letter, but turns out to be two letters, one from the artist to his dead grandmother and another to his newly born daughter. Text and language are perhaps the two technologies which most profoundly shape our lives. By altering our perception and engagement with text, Kac raises questions about the way in which we communicate and understand each other. In his beautiful holopoems, such as Adhuc (1991) displayed in the Furtherfield exhibition, Kac created texts which shift and change depending on the angle at 
which they are viewed. ${ }^{21}$ Text technologies frequently give the impression of immutability, but Kac's holopoems remind us how unstable and deceptive texts may be. Particularly fascinating is the way in which Kac has explored the poetic possibilities of technologies which are now redundant. Thus, Kac used the French videotext network Minitel to show the possibilities of network art. He demonstrated the potential of large-scale collaborative works by various pieces using fax. Although the platform on which these works were realised are now obsolete, the works nevertheless anticipate contemporary digital cultures. In these ways, artistic practice generates vision and expectations of technological possibilities in ways that can shape innovation. This is also apparent from the way Kac was already experimenting with the potential of telepresence, robotics and wearables in the 1990s.

At each point in these explorations, Kac urges us to engage with these technologies creatively, to use them to create fresh visions, and not simply to accept them as consumers. In these ways, Kac's message is an important one for the digital humanities world that I inhabit. Kac is urging us not to passively accept the technological resources and tools made available to them by commercial companies and others. One of the reasons why I believe passionately that humanities scholars should engage more closely with artistic practice is that such a dialogue will foster a more creative and critical approach to the use of digital methods by humanities scholars. The artists whose work I have encountered in the course of my AHRC Fellowship, such as Fabio Lattanzi Antinori, Michael Takeo Magruder, and Katriona Beales as well as pioneers such as Nam June Paik all convey the message that we need to engage creatively with technology. Technology is a threat if we view it passively as an inhuman external force; if we rather seek, like Kac and these other artists, to interrogate, extend and reimagine technology in a creative way we can hope to take greater ownership of it.

These issues become all the more evident and pressing when we turn to Kac's bio-art.22 It is becoming increasingly evident that new biotechnologies will within a short period of time profoundly alter human existence and personality. In the wake of the COVID-19 pandemic, the importance of biology for the future of humanity has become particularly apparent. Kac's bio-art (following in a tradition (1991), Adhuc, was a holographic work that produces scent. Artist, edition of three.

22 (2007), Signs of Life: Bio art and Beyond, (Cambridge, MA: MIT Press). 
23 Eduardo Kac (1999), Genesis, (Linz: O.K. Center for Contemporary Art), 45-55.

Cf Gerfried Stocker and Christine

Schopf, Eds.

(1999), Ars

Electronica

99-Life Science,

(Vienna /New York:

Springer), 310-13.

Currently situated

at the Collection

Instituto de Arte

Moderno (IVAM),

Valencia, Spain,

ekac.org/geninfo2. html

24 As quoted in Scott Weintraub (2018), Latin American Technopoetics: Scientific Explorations in New Media, New Hispanisms: Cultural and Literary Studies, (New York and London:

Routledge), 114. which includes the creation of germ pictures by Sir Alexander Fleming) again encourages us to engage creatively with these emerging technologies.

DNA is text and DNA can be poetry of the most profound sort. In a series of works called Genesis (2001), a synthetic gene was created by Kac by translating a sentence from the biblical book of Genesis into Morse code, and converting the Morse code into DNA base pairs according to a conversion principle developed by the artist. ${ }^{23}$ The sentence chosen was Genesis 1:26: "Let man have dominion over the fish of the sea, and over the fowl of the air, and over every living thing that moves upon the earth." Visitors to the gallery showing Genesis could trigger mutations in the bacteria's DNA by switching an ultraviolet light on and off. This in turn mutated the text when it was converted back in Morse code and then into English. The artist comments that "the ability to change the sentence is a symbolic gesture: it means that we do not accept its meaning in the form we inherited it, and that new meanings emerge as we seek to change it." ${ }^{24}$ GFP Bunny (2000) is the most famous of the pioneering transgenic art works created by Kac. The image of Alba, an albino rabbit genetically modified so that, when illuminated with light at a particular wavelength, she glows fluorescent green, became one of the first iconic images of the twenty-first century. As a result of the international controversy and debates generated by GFP Bunny, depictions of fluorescent green rabbits appeared widely in newspapers, magazines and television.

'Alba' is Latin for white and also Italian for dawn. She was an albino rabbit with no skin pigment, so that under ordinary environmental conditions, she appeared completely white with pink eyes. However as she was created with EGFP, a synthetically-enhanced version of the fluorescent gene found in the jellyfish Aequorea Victoria, she would glow when illuminated with blue light (maximum excitation at $488 \mathrm{~nm}$ ). Then she would glow with a bright green light (maximum emission at $509 \mathrm{~nm}$ ). GFP stands for Green Fluorescent Protein. Kac described his intentions with GFP Bunny as follows:

"The first phase of the GFP Bunny project was completed in February 2000 with the birth of Alba in Jouy-en-Josas, France. This was accomplished with the invaluable assistance of the zoosystemician Louis Bec and scientists Louis-Marie Houdebine and 


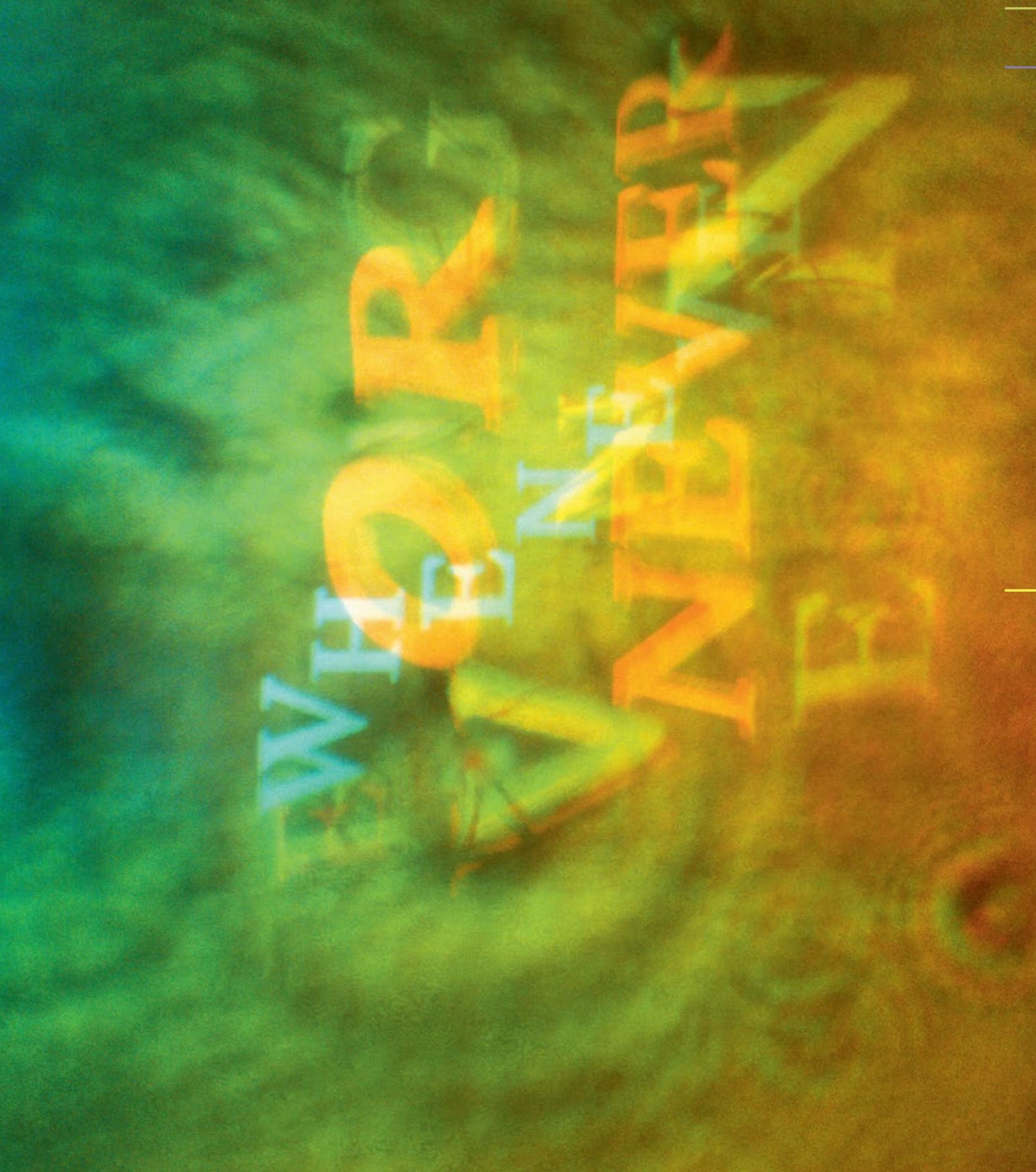


25 Eduardo Kac (2000), GFP

Bunny, in Peter T. Dobrila and Kostic Aleksandra (Eds.)

Eduardo Kac:

Telepresesence, Biotelematics, and Transgenic Art, (Maribor: Kibla). Online at www. ekac.org/gfpbunny. html\#gfpbunnyanchor

26 "Scientists at the French Agricultural Research Institute have refused to give a genetically modified rabbit to Eduardo Kac, a Chicago artist who wants the animal as a work of art. They deny that Alba, a lab pet with a jellyfish gene, is green but say she has a slight hue." as quoted in "Hop off...," The Times (London: October 2000).
Patrick Prunet of the Institut National de la Recherche Agronomique in France." As Kac continues:

"Alba's name was chosen by consensus between my wife Ruth, my daughter Miriam, and myself. The second phase is the ongoing debate, which started with the first public announcement of Alba's birth, in the context of the Planet Work conference, in San Francisco, on 14 May 2000. The third phase will take place when the bunny comes home to Chicago, becoming part of my family and living with us from this point on." 25

Alba never went to live with the artist's family. An article in the Boston Globe on 17 September 2000 reported "As word has slowly leaked out about Alba-who was supposed to 'interact' with Kac in a faux living room as a piece of performance art, but is instead confined to her French laboratory after protests-it is bringing outcries from scientists and animal rights activists, shocked at the idea that the powerful tools of biotechnology would be used for an art exhibit." 26

The public discussion sparked by GFP Bunny led to articles in newspapers and magazines from America and Australia to Poland, Sweden and Romania. These were frequently illustrated by a photograph of a fluorescent Alba, popularising this image. The idea of a fluorescent bunny even excited newspaper cartoonists in France and Australia. The public debate was further enhanced in December 2000 when Kac launched a campaign in France to bring Alba home. This intervention included a poster campaign at various sites in Paris, newspaper, radio and television interviews, and public 
27 Eduardo Kac (2010), Lagoglyphs, Genetic Art (video), Streaming Museum, at streamingmuseum.org/ eduardo-kac-lagoglyphs/

28 Cf Eduardo Kac (2009),

Lagoglyphs, Biotopes and Transgenic works, curated by Christiane Paul at Oi Futuro, Rio de Janeir, Brazil, 25-30 Jan at ekac.org/oi_kac. show_overview. html. Cf Lagoogleglyph II (2015) at esbaluard.org/en/ obras/lagoogleglyph-ii-2/. Cf Lagoogleglyph III (2018) at furtherfield.org/ poetry-for-animals-machinesand-aliens-the-artof-eduardo-kac/ lectures and debates. Alba quickly became an international rabbit cause célèbre. In the wake of the public controversy and the campaign to release Alba from the laboratory, Eduardo Kac produced a series of works inspired in different ways by Alba. The Alba Flag (2001) was hung outside the artist's house as a memento of Alba's absence and a beacon to guide her home. Kac's memories of Alba prompted him to create a wordless language incorporating rabbit imagery which he called Lagoglyphs (from the ancient Greek words lagos for hare and glyphe for carving).

The Bunny Variations (2007) are bichrome silkscreens demonstrating this leporimorph or rabbitographic writing. As Kac later commented, "As visual language that alludes to meaning but resists interpretation, the Lagoglyphs series stands as the counterpoint to the barrage of discourses generated through, with, and around GFP Bunny." 27 In this way, the Lagoglyphs were almost a commentary anticipating the comparable barrage of discourse unleashed on the world by the proliferation of social media in the decade following Bunny Variations. Kac began a series of Lagoogleglyphs, large lagoglyphs designed to be visible from the satellites which provide the imagery for Google Earth. Lagoogleglyph I (2009) was installed at Oi Futuro, Rio de Janeiro, Brazil and Lagoogleglyph II (2015) at Es Baluard Museum of Modern and Contemporary Art, Palma de Mallorca, Spain.

Lagoogleglyph III was installed in Finsbury Park during the Furtherfield exhibition in 2018. ${ }^{28}$ The Lagoogleglyphs represent another striking commentary on, and subversion of, our shared digital world. Google is a vast all-encompassing technology giant which encourages us to consume its services while it makes money from data about us. The way in which Google Earth acts as a panopticon for the world, presenting an idealised sunny view of the planet's surface, symbolizes the hierarchical downward nature of much modern technology. How can we seek to make our presence felt with the world of mass corporate technology? Painting a huge image in Finsbury Park is an inspired way of intervening in the artificial deracinated corporate view of the human world presented in Google Earth.

While the Lagoogleglyphs made direct points about reimagining technology, Alba became an extraordinary cultural phenomenon, anticipating an internet meme before memes became commonplace. The process by which Alba escaped into the outside world and 
spawned innumerable offspring, provides a fascinating case study in cultural dynamics. This was the focus of the exhibition at the Horse Hospital in June 2018. The story of how 'the bunny went pop' raised questions as to the relationship between science, pop culture, ethics and art. It continues to do so in a way that remains both prescient and pressing in a world where American President Trump suggests injecting bleach as a way of dealing with a global pandemic. As Ferran puts it in the handout accompanying the Horse Hospital exhibition:

"Who is Alba? What is she? Concept or chimera? The stuff of dreams or the stuff of nightmares? This bifurcation of uncertainties lies at the heart of this exhibition about the multiple lives in myriad media of a metamorphosing green bunny whose presence in contemporary pop culture is now indelible. Conceived as a radical work of art by Eduardo Kac in 2000, his concept has been subsumed into a global phenomenon that offers a dark, playful mirror to collective uncertainties ... Is everything pop culture now? Is Alba an autopoeitic spokes-bunny for the arts of metamorphosis in the domain of media appropriation? Is glowing in the dark the endgame or our ultimate dream of escape?" 29

From the outset Kac saw the public dialogue generated by GFP Bunny as integral to the artwork. However, the scale and extent of the public response took him by surprise. While the creation of Alba sparked public debate, including some criticism of Kac on ethical grounds by some of his artist-peers, GFP Bunny nevertheless helped spread educational and public awareness of the underlying science. ${ }^{30}$ The chemists who developed the green fluorescent protein won the Nobel Prize in 2008, and alluded to Kac's work in their acceptance speech. Alba was used to explain biotechnology in children's books and popular science publications. In Brazil, questions about Alba featured in high school examination papers, and many high school children became familiar with the image of Alba from their text books. This initial discussion of GFP Bunny was however only the first stage in the process by which the bunny went viral. It is sometimes assumed that the proliferation of cultural memes is due largely to the internet. However, the initial debates around GFP Bunny were dominated by more conventional media: newspapers, magazines, television, radio, public debate and performance. Moreover, the subsequent and most influential stages of the process by which the idea of a fluorescent
29 Bronac Ferran (co-curator), $A$ Proliferation of Uncertainties: The Autopoiesia of Alba, Introductory Text, London: Horse Hospital exhibition, 2-23 June 2018 at www.ekac.org/ bunnypop.html

30 See Carrie Dierks (2000), "Glowing Bunny Sparks International Controversy", in Biology News, (Dery: Peregrine Publishers), at peregrine-pub.com/ news/bunny.html 
31 Margaret Atwood (2004), Oryx and Crake. The Maddaddam Trilogy Book 1, (London: Virago).
32 Atwood, Oryx and Crake. 109-10. green bunny was taken up by a wide range of creative artists was transmedia in character and not restricted to the internet. The bunny appeared in films, novels, TV programmes, cartoons and as a toy. The internet undoubtedly accelerated this process and extended its international reach, but was not the reason the bunny went viral. The internet enables us more easily to investigate and document the bunny's journey, but it does not explain the world's bunny mania. Alba was extensively appropriated by a number of authors and artists, with and without acknowledgement, from her earliest appearance. Some of these became so influential that the idea of a fluorescent green rabbit is now better known through these channels than from Kac's original artwork. What is striking about this process is the way in which the concept has moved from dystopian views of biotechnologies, during the years immediately after Alba's birth, to a more commercialised and arguably sanitised view in recent manifestations. One of the issues raised by the way in which the bunny went viral is to what extent these shifting views reflect underlying cultural and social trends.

First, in 2003 author Margaret Atwood published Oryx and Crake, a dystopian novel describing a degraded and depraved world in which biotechnology companies have unlimited wealth and power and all life is commodified. ${ }^{31}$ A plan to modify genetically the human being eventually leads to its destruction. Atwood's novel is packed with many strange transgenic creatures, such as the Hyena Swine (a cross of pig and hyena), M'ling (a hybrid of bear, dog and ox). Pigoons (pigs bred to grow human organs) and Wolvogs (that have the appearance of dogs and savageness of wolves). Among the first of these transgenic creatures to be created, according to Atwood, was a fluorescent bunny:

"Across the clearing to the south comes a rabbit, hopping, listening, pausing to nibble at the grass with its gigantic teeth. It glows in the dark, a greenish glow filched from the iridicytes of a deep-sea jellyfish in some long-ago experiment. In the half-light the rabbit looks soft and almost translucent, like a piece of Turkish delight; as if you could suck off its fur like sugar." ${ }^{32}$ Oryx and Crake was one of Atwood's most successful novels and a television adaptation is in development, which will doubtless feature the green rabbits. Many illustrations of Oryx and Crake give 
33 GFP Bunny, directed by Yutaka Tsuchiya, Tokyo: UPLINK Co, 2012, 82' Cf: http://2012. tiff-jp.net/en/ lineup/works. php?id=132 prominence to fluorescent rabbits but without referencing Alba, as original inspiration. Oryx and Crake was the first of a trilogy, and green rabbits also figure in the other novels in the trilogy, Year of the Flood (2009) and Maddadam (2013).

The second major development in the media career of Alba occurred in 2012, when the Japanese director Yukata Tsuchiya premiered his metafictional remix, GFP Bunny, at the Tokyo International Film Theatre a film inspired by a scandal which had shocked Japan, when a schoolgirl had tried to poison her mother with thallium. ${ }^{33}$ Tsuchiya's film explored the girl's motives by examining her other interests, which included experiments in dissection, genetic engineering and bio-art. Among the characters encountered by the girl are a biologist who created a transparent frog and an artist who implants a chip with GPS in her hand (echoing Kac's own 1997 work Time Capsule). At the end of the film, the girl rides off on a motorcycle with Takahashi, a body modification artist.

This film won the best picture award in the Japanese Eyes section of the Tokyo International Film Festival and has been shown at many other major international film festivals including Rotterdam, Singapore, Taipei, Hamburg and Montreal. By agreement with Eduardo Kac, the English title of the film was GFP Bunny. As a result, this Japanese film came to occupy the GFP Bunny space in social media. The only GFP bunny domain in use on the web is that used by the film: gfp-bunny.info. The Facebook and Twitter accounts for gfpbunny are used by the film. (The gfpbunny Instagram account is owned by James Matthew, an American epidemiologist who is doubtless aware of Kac's work but does not refer to it in his Instagram account). The Japanese film not only took the idea of the GFP bunny to new audiences but also effectively colonised its social media presence.

The third and perhaps most influential media appropriation of Alba occurred in 2012. In reworking Sir Arthur Conan Doyle's story The Hound of the Baskervilles for the BBC TV series Sherlock (as The Hounds of Baskerville), the scriptwriter Mark Gatiss read about Kac's GFP Bunny. Realising how the genetic engineering could be used to update Conan Doyle's plot device of luminous paint, Gatiss introduced a side plot in which a scientist at the top secret base of Baskerville had created a glow-in-the-dark bunny called Bluebell. 

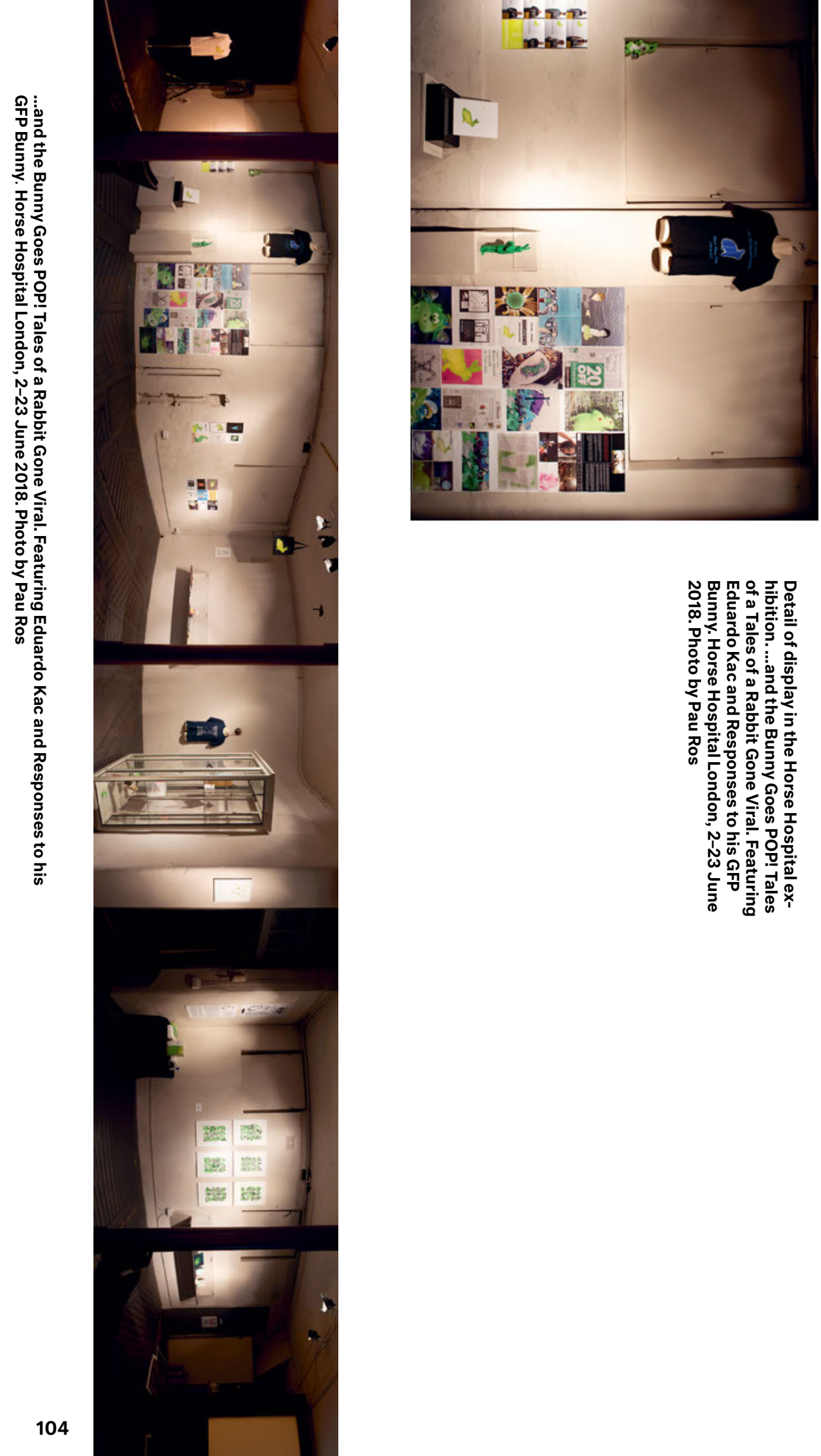
produced featuring The Lost Village, including toy packs with luminous bunnies. At one level, the Smurfs and McDonald's Happy Meals might be seen as representing a sanitisation of the vision of Alba presented in Oryx and Crake. However, at another level, references to transgenic animals in animated films and in hamburger merchandising might be taken as indicating that we are on the path to the dystopian world described by Atwood.

The glow bunny Smurf toys were licenced with the full weight of Sony's commercial might, although Sony itself appropriated the idea of the glow bunny from Kac and the GFP Bunny. It will be interesting to see whether Sony tries to restrict the cultural proliferation of fluorescent rabbits and what effect this commercialisation has on Alba's continued dissemination. Do the Smurfs and McDonald's represent the end of Alba's journey? Probably not. Alba is now a creature of the internet.

Glowing creatures permeate popular art, as sites such as Deviantart reveal. Patrick Lichty, Peer Hansen and Rachel L have taken the cultural commentator McKenzie Wark's mesh of Guy Debord, and added an ear on the back (in honour of Stelarc) and Bunny Ears (in honour of Eduardo Kac). ${ }^{34}$ This Detournement \#1 of Patrick Lichty, Peer Hansen and Rachel L. Patrick Lichty, Peer Hansen and Rachel L McKenzie Wark's Guy Debord: Kac/Stelarc Remix is available under a Creative Commons licence in Patrick Lichty, Peer Hansen and Rachel $L$ Thingiverse, so that Alba responses are now being 3D-printed. It seems that Alba will run and run. When the Arts and Humanities Research Council established its strategic theme of Digital Transformations, the terminology echoed that used in many corporate contexts, and was redolent of improved business processes and data management. This continues to be a dominant thread in research council strategies for digital technologies with investment in infrastructure receiving a great deal of prominence since the creation of UK Research and Innovation. However, the work of Eduardo Kac's work reminds us that real digital transformations are achieved through creative interrogation of technology and through reimagining how we engage with that technology. In thinking about the poetics of technology, different perspectives and possibilities emerge which aren't at first evident in spreadsheets.

Poetics turn out to be true drivers of digital transformation.
34 Cf Detournement \#1 of McKenzie Wark's Guy Debord: Kac/Stelarc Remix at thingiverse. com/thing:95311 See also Stelarc's commentary on his Third Ear at Stelarc, Ear on Arm: Engineering, internet, organ at stelarc. org/?catID=20242 


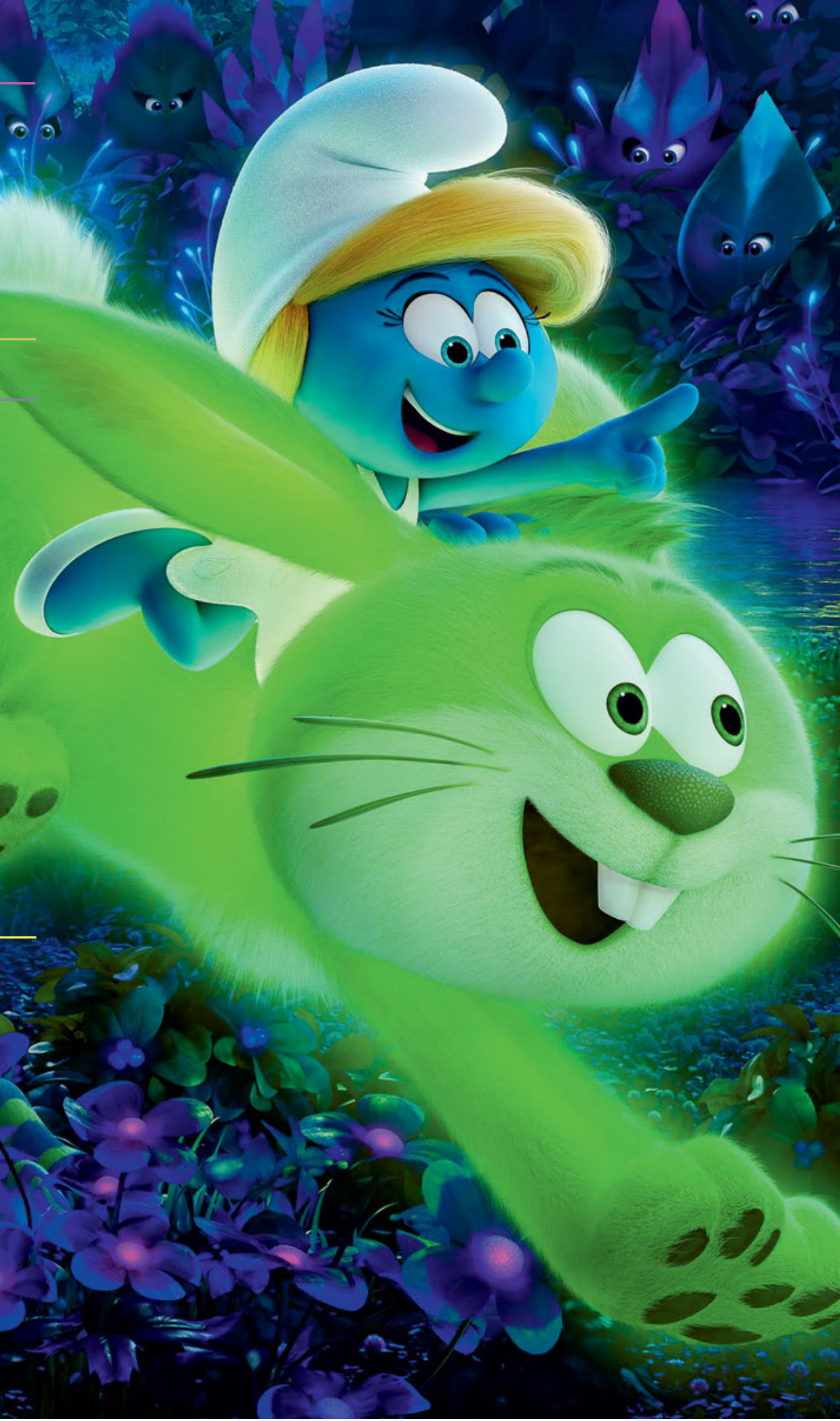

Smurfs: The

Lost Village.

Advertisement

by Sony Pic-

tures, 2017.

curiosity [,kjuərı'psiti]

foundation of

knowledge in the

fullest sense of the

word: science, art,

philosophy, indeed

life itself. curios-

ity (sapere aude!

dare to know)

remains the bane

of existence for

authoritarian re-

gimes, and frankly all those who get

nervous about

change (from, say,

sexual, racial, gen-

dered repression

to a more human

rights egalitarian

type of adventure).

as it turns out,

that's a whole lot

of people, possibly

including your

good self. 